\title{
The N-Methyl-D-Aspartic Acid Receptor Antagonist Memantine Ameliorates and Delays the Development of Arthritis by Enhancing Regulatory T Cells
}

\author{
Sofia S. Lindblad Piotr Mydel Annelie Hellvard Ing-Marie Jonsson \\ Maria I. Bokarewa \\ Department of Rheumatology and Inflammation Research, University of Gothenburg, Sahlgrenska University \\ Hospital, Göteborg, Sweden
}

\section{Key Words}

$\mathrm{N}$-Methyl-D-aspartic acid receptor $\cdot$ Collagen-induced arthritis $\cdot$ Regulatory T cells

\begin{abstract}
The neuroendocrine impact on rheumatoid arthritis is not yet fully described although numerous neurotransmitters are shown to act as inflammatory modulators. One of these is the excitatory transmitter glutamate (Glu). In this study, the influence of the Glu receptor (GluR)-mediated effects on collagen-induced arthritis (CIA) was investigated. CIA was induced in DBA/1 mice by immunization with chicken collagen type II (CII). Mice were exposed to the following GluR antagonists: group 1, the N-methyl-D-aspartic acid (NMDA) receptor channel blocker memantine; group 2, the metabotropic GluR antagonist AIDA, and group 3, the excitatory amino acid receptor antagonist kynurenic acid (KA). Arthritis was evaluated clinically and histologically and compared to PBStreated controls. The effects of treatment on T cell populations and the levels of anti-Cll and anti-citrullinated peptide antibodies were evaluated. Memantine treatment significantly improved the course of $\mathrm{CIA}$, reducing synovitis ( $\mathrm{p}=$ $0.007)$ and the frequency of erosions ( $p=0.007)$. Memantine treatment up-regulated the expression of Foxp3 in spleen
\end{abstract}

CD4+ $T$ cells followed by an increase in CD4+CD25+ regulatory $T$ cells. The other GluR antagonists, AIDA and KA, had no effect on $\mathrm{CIA}$. These results demonstrate that blockade of the NMDA receptor channel with memantine delays and attenuates the development of arthritis, probably by promoting the development of regulatory $T$ lymphocytes.

Copyright $\odot 2011$ S. Karger AG, Basel

\section{Introduction}

Rheumatoid arthritis (RA) is a chronic autoimmune disease characterized by severe joint inflammation, progressive joint destruction and disability. Morphologically, RA is characterized by excessive growth of the synovial tissue, which forms an invasive pannus that degrades joint cartilage and subchondral bone. Although the pathogenesis of RA is not fully understood, it is generally accepted that $\mathrm{T}$ cells play a pivotal role in the joint inflammation and disease progression. Functional dysregulation of T cells is a crucial step in the development of RA, and this process includes antigen presentation, excessive proliferation and homing to synovial tissues. The antigen-dependent $\mathrm{T}$ cell response causes production of antibodies against autoantigens, such as immunoglobulins

\section{KARGER}

Fax +41613061234 E-Mail karger@karger.ch www.karger.com

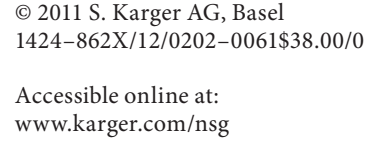

Sofia Silfverswärd Lindblad, $\mathrm{PhD}$

Department of Rheumatology and Inflammation Research

Sahlgrenska Academy, University of Göteborg, Guldhedsgatan 10 A

SE-413 46 Göteborg (Sweden)

Tel. +46 3134229 62, E-Mail sofia.lindblad@ @heuma.gu.se 
(rheumatoid factor) and citrullinated proteins, which are important early markers of the disease [1]. T cells from RA patients can activate monocytes/macrophages and fibroblasts that induce the production of inflammatory cytokines such as TNF- $\alpha$, MIP-1 and MCP-1 [2], as well as IL-6 and IL-8 [3]. T cells contribute to the excessive bone metabolism in RA, which occurs via the induction of osteoclastogenesis [4]. The $\mathrm{T}$ cell population comprises a range of clones with diverse functions (e.g. helper, effector and suppressor), and these cells play distinct roles at different stages of the disease, creating a complex network of cellular interactions [5]. A shift to the Th1 proinflammatory population, which results in relative suppression of regulatory $\mathrm{T}$ cells and loss of self-tolerance, is one of the basic mechanisms of the development of RA [1].

Glutamate (Glu) is the most abundant excitatory neurotransmitter in the mammalian nervous system [6]. Numerous studies have demonstrated increased levels of excitatory neurotransmitters, including Glu and aspartate (Asp), in the synovial fluid of patients with active arthropathies, as well as in animal models of arthritis [710]. A number of cells of importance in the RA joint pathology express Glu receptors (GluRs). In addition to T cells, chondrocytes, osteoblasts, osteocytes, osteoclasts, fibroblasts and synoviocytes express functional N-methyl-D-aspartate (NMDA) receptors [11, 12], which suggests that they may be of pathological importance in the development of RA. Since Glu is involved in signalling in immunocompetent cells, as well as in the nervous system, it is proposed to act as a signalling agent between the immune and nervous systems [13].

GluRs are divided into two categories: ionotropic and metabotropic. There are three different ionotropic GluRs (iGluRs): the NMDA receptor, the kainate receptor and the $\alpha$-amino-3-hydroxy-5-methyl-4-isoxazolepropionic acid (AMPA) receptor. The G protein-coupled metabotropic receptors (mGluRs) contain seven transmembrane-spanning domains and these receptors can be divided into eight different subtypes (mGluR1-8), depending upon structure and physiological activity [14]. The NMDA receptors are ligand-gated ion channels. For efficient opening of the ion channel, activation requires binding of Glu or Asp, as well as binding of the co-agonist glycine and membrane depolarization [15]. The NMDA receptor plays a key role in a wide range of physiologic processes including synaptic plasticity [16]. NMDA receptor activity is modulated by endogenous compounds, such as zinc ions, polyamines and protons [17], and is antagonized by various anaesthetics [18] and recreational drugs, including ethanol and phencyclidine $[19,20]$. The mGluRs perform a number of different functions in the central and peripheral nervous system: they are involved in learning, memory, anxiety and sensation of pain [21, 22]. mGluRs are also known to facilitate the activity of NMDA receptors [23].

Human T lymphocytes express receptors for a variety of neurotransmitters, which influences their activation via specific receptors [24]. Evidence for GluRs in nonneuronal cells emerged in the 1990s [25], and it has recently been reported that $\mathrm{T}$ cells express both iGluRs and mGluRs [26]. mGluR1 is expressed after CD3-dependent activation of T cells while mGluR 5 is expressed constitutively on lymphocytes [27].

In the present study, we evaluated the role of different GluRs in the development of arthritis using an established mouse model of collagen-induced arthritis. Glu signalling was abrogated selectively with antagonists of (a) the iGluR NMDA using memantine, (b) the group 1 mGluR1 using $(R, S)$-1-aminoindan-1,5-dicarboxylic acid (AIDA), and (c) broad-spectrum excitatory amino acid receptors using kynurenic acid (KA). The NMDA receptor antagonist memantine is classified as an open-channel blocker, i.e. it enters the NMDA receptor channel and blocks current flow only after channel opening [28]. AIDA is a potent and selective antagonist of the mGluRla having no effect on group 2 (mGluR2) or group 3 (mGluR3) receptors. AIDA has no effect on iGluRs. KA, a tryptophan metabolite synthesized in astrocytes, is an endogenous substance acting as a non-competitive antagonist at the glycine site of the NMDA receptor. It is considered a broad-spectrum excitatory amino acid receptor antagonist as it, in addition to the NMDA receptor, blocks the $\alpha 7$-nicotinic acetylcholine receptor.

Memantine was found to attenuate and delay the development of collagen-induced arthritis (CIA). Additionally, inhibition of the NMDA receptor induced the expression of transcription factor Foxp3 in CD4+ T lymphocytes, and this was followed by an increase in the CD4+CD25+ regulatory $T$ cell population. These findings provide a plausible mechanism for the anti-arthritogenic effect of the NMDA receptor channel blockade seen in memantine-treated mice.

\section{Material and Methods}

Mice

Male DBA/1 mice (age 6-8 weeks, $\mathrm{n}=101$; Taconic Europe $\mathrm{A} / \mathrm{S}, \mathrm{Ry}$, Denmark) were used in the CIA experiments. All animals were kept under standard pathogen-free environmental condi- 
tions and had free access to standard laboratory chow and drinking water. Ethical permission was obtained from the Animal Research Ethics Committee of University of Gothenburg.

\section{Collagen-Induced Arthritis}

Chicken collagen type II (CII; Sigma) was dissolved to the concentration of $2 \mathrm{mg} / \mathrm{ml}$ in $0.1 \mathrm{M}$ acetic acid. DBA/ 1 mice were immunized at the base of the tail by a subcutaneous injection of 100 $\mu \mathrm{g}$ CII emulsified in an equal volume of complete Freund's adjuvant (Sigma). A booster immunization containing $100 \mu \mathrm{g}$ of CII in incomplete Freund's adjuvant was administered subcutaneously at the base of the tail on day 21 after the first immunization. The mice were regularly weighed, and clinical evaluation of joints for signs of arthritis was performed every other day. Blood samples were taken from the jugularis vein for serological analyses of cytokines, antibodies and markers of bone metabolism. Histological changes and bone mineral density were assessed in the paws.

\section{Treatment with GluR Antagonists}

Three different GluR antagonists were administered to CIA mice starting from immunization day 0 throughout the experiment. The first group was treated with memantine $\left(\right.$ Ebixa $^{\circledR}$; Lundbeck, Denmark), a blocker of the NMDA receptor channel. Memantine was administered intraperitoneally every $12 \mathrm{~h}$ in a final volume of $100 \mu \mathrm{l}$. Treatment was initiated with a loading dose of $20 \mathrm{mg} / \mathrm{kg}$ and $24 \mathrm{~h}$ later, a maintenance dose regimen of 1 $\mathrm{mg} / \mathrm{kg}$ every $12 \mathrm{~h}$ was started and continued throughout the experiment [29]. Memantine treatment was administered in three independent experiments to a total of 28 mice. The second group received a selective antagonist of mGluR1 (mGlula and mGlu5), AIDA (Tocris Bioscience, Bristol, UK) at the dose of $2.5 \mathrm{mg} / \mathrm{kg}$ administered intraperitoneally every $24 \mathrm{~h}$. AIDA treatment was used in one experiment in a total of 7 mice. The third group was treated with the broad-spectrum excitatory amino acid antagonist KA (Tocris Bioscience) at the dose of $2.5 \mathrm{mg} / \mathrm{kg}$, administered intraperitoneally every $24 \mathrm{~h}$. KA treatment was used in two independent experiments in a total of 13 mice. The experiments with AIDA and KA treatment were discontinued on day 41. Each experiment included a vehicle (PBS)-treated control group ( $n=10$ 12 per experiment) to which the antagonist-treated groups were compared. Mice of the control group were injected PBS intraperitoneally every $24 \mathrm{~h}$ in a final volume of $100 \mu \mathrm{l}$. In a separate experiment, memantine was administered to CIA mice $(n=9)$ from the booster immunization on day 21 using the treatment protocol described above. Control CIA mice $(n=9)$ were administered PBS. The latter experiment was discontinued on day 43. For evaluation of the $\mathrm{T}$ lymphocyte subsets and functions, mice were treated with memantine $(\mathrm{n}=10), \operatorname{AIDA}(\mathrm{n}=5)$ and PBS $(\mathrm{n}=10)$ as described above for 7-12 days.

\section{Clinical and Histological Evaluation of Arthritis}

To assess the intensity of arthritis, a clinical scoring system of $0-3$ points for each paw was used: $0=$ no sign of inflammation; $1=$ mild swelling and/or erythema; $2=$ moderate swelling and erythema, and $3=$ marked swelling and erythema. The arthritic index was constructed by adding the scores of all four limbs of each animal. The frequency of arthritis represents the proportion of mice exhibiting any signs of clinical arthritis.

Glutamate Receptors and $\mathrm{T}_{\text {reg }}$ in Rheumatoid Arthritis
Tissue sections of all four paws from DBA/1 mice that had been excised at the end of experiments were imbedded in paraffin, cut in 3- $\mu$ m-thick slices and stained with haematoxylin/eosin and safranin-O. The sections were evaluated for synovitis and erosion of bone/cartilage by a blinded examiner. Synovial hypertrophy (synovitis) was defined as membrane thickness of more than two cell layers. A histological scoring system of synovitis was used as follows: 1 = mild; 2 = moderate, and 3 = severe [30]. Knee joints, ankles, elbows, wrists and interphalangeal joints of all four extremities were inspected, and a mean score for all inspected joints was calculated.

\section{Preparation of Leukocytes}

Leukocytes were isolated from spleens of DBA/1 mice treated for a period of 7-12 days with intraperitoneal injections of memantine $(1 \mathrm{mg} / \mathrm{kg})$ or PBS. Splenocytes were applied on plates at $37^{\circ} \mathrm{C}$ in complete medium pending flow-cytometric analysis. For the assessment of $\mathrm{T}$ cell function, regulatory $\mathrm{T}$ cells and responder T cells were isolated using two-step Dynabeads ${ }^{\circledR}$ FlowComp ${ }^{\mathrm{TM}}$ Mouse CD4+CD25+ Treg Cell kits (Invitrogen). CD4+ cells were obtained by negative selection followed by positive selection of CD4+CD25+ regulatory T cells. CD4+CD25- cells were used as responder $\mathrm{T}$ cells. Flow cytometry showed Foxp3 expression in $77.6 \%$ of the obtained CD4+CD25+ cells.

\section{Lymphocyte Functional Assay}

CD4+CD25- T cells were seeded in 96-well flat-bottom plates and CD4+CD25+ regulatory $\mathrm{T}$ cells were added at a ratio of $4: 1$ and 8:1 to a final cell concentration of $2 \times 10^{6}$ cells $/ \mathrm{ml}$. Lymphocyte mixtures were cultured in complete medium (Iscove's modified Dulbecco's medium enriched with $50 \mu \mathrm{g} / \mathrm{ml}$ gentamycin (Sigma), $4 \mathrm{~mm}$ L-glutamine (Sigma), $50 \mu \mathrm{M}$ mercaptoethanol (Sig$\mathrm{ma}$ ), and 10\% FCS (Biological Industries, Beit Haemek, Israel) for $48 \mathrm{~h}$ in the presence or absence of anti-CD3 $(0.5 \mathrm{ug} / \mathrm{ml})$. Supernatants were collected for the assessment of cytokine production. Proliferation of the lymphocyte cultures was measured by the incorporation of $\left[{ }^{3} \mathrm{H}\right]$ thymidine (Amersham Pharmacia Biotech, Uppsala) overnight as described by Chen et al. [31]. Proliferation of CD4+CD25- culture was set as 100\% functional. A reduction in proliferation in the CD4+CD25-/CD4+CD25+ cultures was attributed to the presence of functional regulatory $\mathrm{T}$ cells.

\section{Flow Cytometry}

Splenocytes were pelleted and incubated with Fc-block (2.4G2; BD Bioscience, Stockholm, Sweden) for $20 \mathrm{~min}$ at room temperature to avoid unspecific binding of Fc receptor. Monoclonal antibodies directly conjugated with phycoerythrin (PE), allophycocyanin (APC), allophycocyanin-H7 (APC-H7), fluorescein isothiocyanate, eFluor ${ }^{\mathrm{TM}} 450$ or biotin were used. Streptavidin conjugated with APC or peridininchlorophyll-protein was used in combination with biotin-labelled antibodies. The following antibodies against surface markers were used for analysis: antiCD25 (7D4 and PC61), anti-CD4 (GK1.5; BD Biosciences, Erembodegem, Belgium) and anti-CD19 (1D3; eBioscience, San Diego, Calif., USA). The antibodies were diluted in PBS to optimal concentrations as previously described [32].

\section{Intracellular Staining}

Expression of Foxp3 was assessed using a PE anti-mouse/rat Foxp3 Staining Set (eBioscience). Following permeabilization, the 
cells were incubated with anti-Foxp3 antibodies or isotype control for $30 \mathrm{~min}$ at $4^{\circ} \mathrm{C}$ in the dark. The cells were resuspended in FACS buffer and collected by flow cytometry $\left(1 \times 10^{5}\right.$ to $5 \times 10^{5}$ cells/sample) using a FACSCantoII (BD-Bioscience) equipped with FACSDiva software. Analyses were performed using FlowJo software (Tree Star Inc., Ashland, Oreg., USA), and fluorochrome minus one (FMO) was used for determination of positive populations and gating.

\section{Serologic Markers of Bone and Cartilage Degradation}

For the quantification of bone resorption, serum levels of fragments of type I collagen (CTX-I) were assessed using an enzymelinked immunosorbent assay (ELISA) kit for RatLaps ${ }^{\mathrm{TM}}$ (Immunodiagnostic Systems, Boldon, UK). For the quantification of cartilage resorption, serum levels of degradation products of type II collagen (CTX-II) were assessed using the CartiLaps ${ }^{\circledR}$ ELISA kit (Immunodiagnostic Systems). For measurements of bone turnover, the levels of the remodelling markers osteopontin (OPN) and osteoprotegrin (OPG), and the osteoclastogenic cytokine receptor activator of nuclear factor $\kappa \mathrm{B}$ ligand (RANKL) were measured in sera using ELISA (R\&D Systems, Minneapolis, Minn., USA). The levels of total MMP-3 were measured using a Quantikine ${ }^{\circledR}$ immunoassay kit (R\&D Systems).

\section{Measurements of Cytokine Levels}

The levels of IL- 6 in sera and supernatants were analyzed employing IL-6-sensitive B9 cells as described in detail elsewhere [30]. The levels of IL-2, IL-4, IL-6, IL-17A, IL-10, TNF- $\alpha$ and INF$\gamma$ in supernatants were measured using the $\mathrm{T}_{\mathrm{H}} 1 / \mathrm{T}_{\mathrm{H}} 2 / \mathrm{T}_{\mathrm{H}} 17$ Cytometric Bead Array (CBA-kit, BD Biosciences) according to the manufacturer's instructions. Briefly, supernatants were serially diluted in assay diluent provided in the kit. A mix of the anticytokine beads was added to the supernatant samples and incubated with the PE-conjugated antibodies for $3 \mathrm{~h}$ at room temperature. Serially diluted cytokines were used for creating standard curves. The samples were analysed on a FACSCantoII fitted with an HTS plate loader (BD Biosciences), and data were analysed using FCAP analysis software (BD Bioscience).

\section{Immunoassay for Antibody Levels}

Quantification of anti-CII antibodies in serum was performed as described elsewhere [33]. Quantification of rheumatoid factor and antibodies against CCP in serum was performed as previously described [34].

\section{Statistical Analysis}

Statistical evaluation was made using the Mann-Whitney U test, the $\chi^{2}$ test or Student's t test. Values are reported as medians and interquartile ranges (IQRs) or means \pm SEM. The Bonferroni correction was used when appropriate.

\section{Results}

Memantine Exposure Delays the Onset and

Progression of CIA

Clinical evaluation of the joints was performed daily, and frequency and severity of arthritis were recorded from day 21 throughout the experiment. The three GluR antagonist-treated groups and the vehicle-treated control group from the same study were statistically compared.

Mice exposed to memantine $(n=28$, pooled data from three independent experiments) developed arthritis significantly later and to a lesser extent than the vehicletreated control group ( $\mathrm{n}=31$, pooled data from three independent experiments). Nine days after the booster immunization with CII on day 30 , joint examinations revealed that only 7 out of the 28 memantine-treated mice showed visible signs of arthritis (25\%), compared to 16 of 31 of the control mice treated with the vehicle (51.6\%). This observation was consistent until day 32 , when 21 of 31 (67.7\%) of the controls exhibited arthritis compared to 12 of $28(43 \%)$ memantine-treated mice $(\mathrm{p}=0.04)$.

In addition to the reduction in frequency of arthritis, the clinical evaluation of joints revealed a significant reduction in arthritis severity in the memantine-treated group compared to the vehicle-treated controls. The cumulative indexes of arthritic severity were based on the presence of swelling and erythema in the joints. The differences in arthritis indexes were evaluated on day 32 $(\mathrm{p}=0.02), 34(\mathrm{p}=0.03)$ and $36(\mathrm{p}=0.04$; fig. 1a). Histological evaluation of the joints at the end of the experiments confirmed that memantine alleviated signs of synovitis and the destruction of bone and cartilage (fig. 2a, b). Only $60 \%$ of the memantine-treated animals showed signs of inflammatory cell infiltration and/or thickening of the synovial membrane [histological index, 0.25 (IQR 0-0.46)] compared to $90 \%$ of the control group [1.04 (IQR 0.46-1.27)]. Cartilage damage was found in $90 \%$ of the vehicle-treated controls [0.71 (IQR 0.36-0.94)] and was over 5 -fold lower in the memantine-treated group [0.13 (IQR $0-0.31$ )], where only $60 \%$ of the animals were affected by erosive damage.

Memantine treatment, initiated after booster immunization on day $21(n=9)$, significantly reduced the severity of arthritis in mice developing joint inflammation as compared to the vehicle-treated controls $(n=9)$ on days $40(\mathrm{p}=0.04)$ and $45(\mathrm{p}=0.02)$ (fig. 2b). The onset and frequency of arthritis were similar.

\section{CIA Is Not Affected by Treatment with AIDA or KA}

Mice treated with the mGlulaR antagonist AIDA ( $\mathrm{n}=$ 7), or with the broad-spectrum excitatory amino acid antagonist KA $(n=13)$, did not display any significant differences in the frequency or severity of arthritis compared to vehicle-treated controls. At day 35, the median arthritic index for AIDA was 4.0 (IQR 0.75-6.5) compared to the vehicle-treated control group in the same 


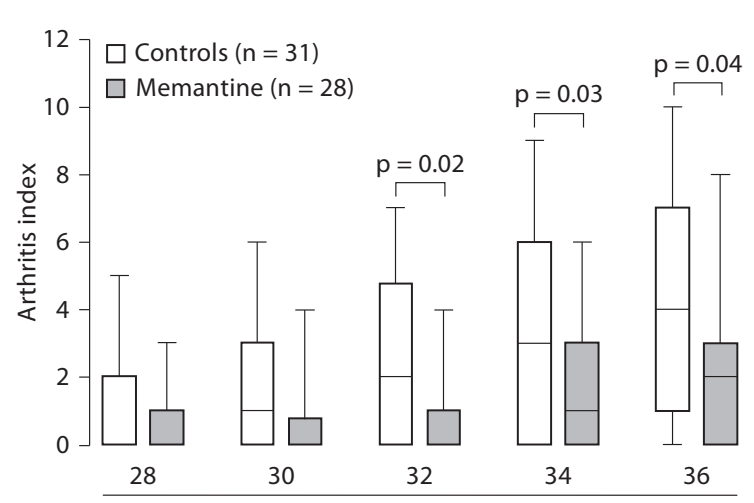

a

Days after immunization

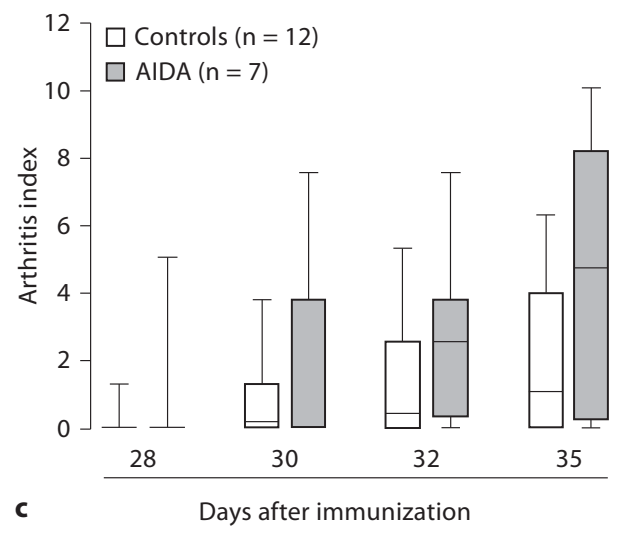

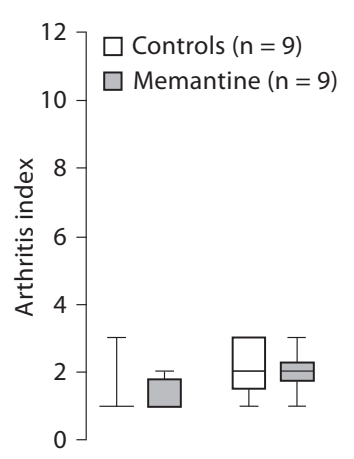
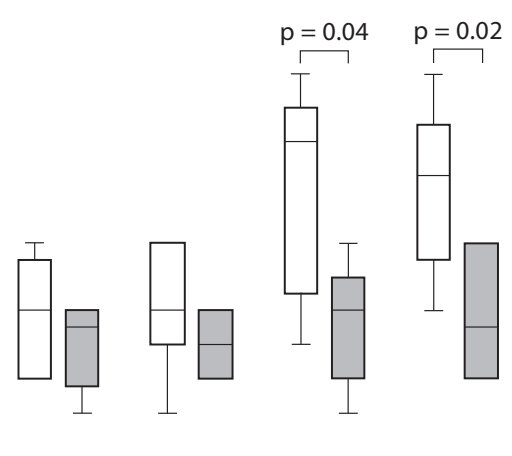

b

\begin{tabular}{llllll}
30 & 32 & 34 & 36 & 40 & 45 \\
\hline
\end{tabular}

Days after immunization

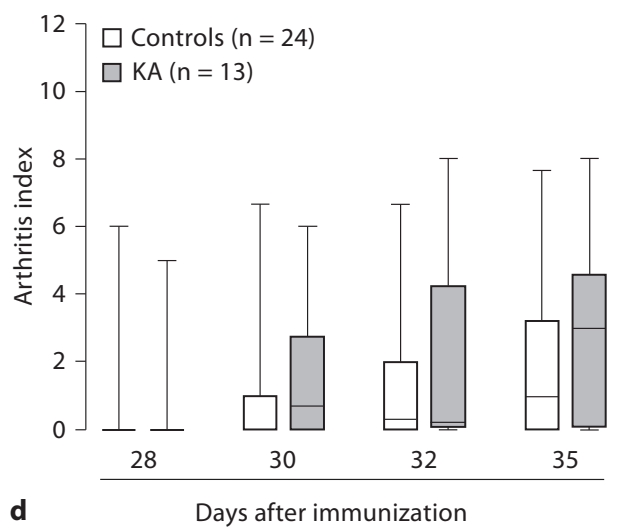

d

Days after immunization
Fig. 1. Memantine exposure reduces the severity of CIA in DBA/1 mice. Mice subjected to CIA were treated with memantine, AIDA or KA from immunization day 1. a Memantine-treated mice displayed significantly less severe arthritis than the control animals. The severity of arthritis is represented by the arthritic index. Significant differences between memantine-treated and control animals were observed at days 32,34 and 36 . b In a separate experiment, memantine treatment was initiated from day 21 of the ex- periment and alleviated clinical signs of arthritis on days 40 and 43. The figure shows the severity of arthritis in mice expressing joint inflammation. $\mathbf{c}$ The progression of CIA was unaffected by treatment with the glutamate receptor antagonists AIDA $(n=7)$ or KA $(\mathbf{d})(\mathrm{n}=13)$. Values are presented as medians and IQR. Horizontal lines indicate the median, whiskers represent minimal and maximal values. Statistical evaluation was performed using the Mann-Whitney U test with Bonferroni correction. experiment with arthritic index 1.5 (IQR 0-3.75). The arthritic index for KA at day 35 was 3.0 (IQR 3.5-4.5) while the vehicle-treated control group in the same experiment had an index of 1.0 (IQR 0-4) (fig. 2c, d). The histological evaluation performed on day 41 supported the clinical data and showed that AIDA and KA had no significant effect on the presence of synovitis and erosion.

\section{Memantine Reduces Bone Resorption in CIA}

To investigate the potential role of memantine on bone metabolism, markers of bone and cartilage resorption were measured. Memantine-treated mice presented significantly lower serum levels of the bone resorption marker CTX-I [n = 18; 17.2 (IQR 15.9-18.93)] compared to vehicle-treated controls [ $\mathrm{n}=17 ; 19.4$ (IQR 16.8521.65)], $(\mathrm{p}=0.04)$ (fig. 2c). No significant differences were detected in the levels of the cartilage degradation marker CTX-II. The bone metabolism markers OPG, RANKL and MMP-3 were expressed at similar levels in the antagonist- and vehicle-treated controls although the levels of the osteoclast stimulator OPN were significantly lower in the memantine-treated group (table 1). Surprisingly, serum levels of the pro-inflammatory cytokine IL- 6 were not significantly reduced in memantine-treated mice. 


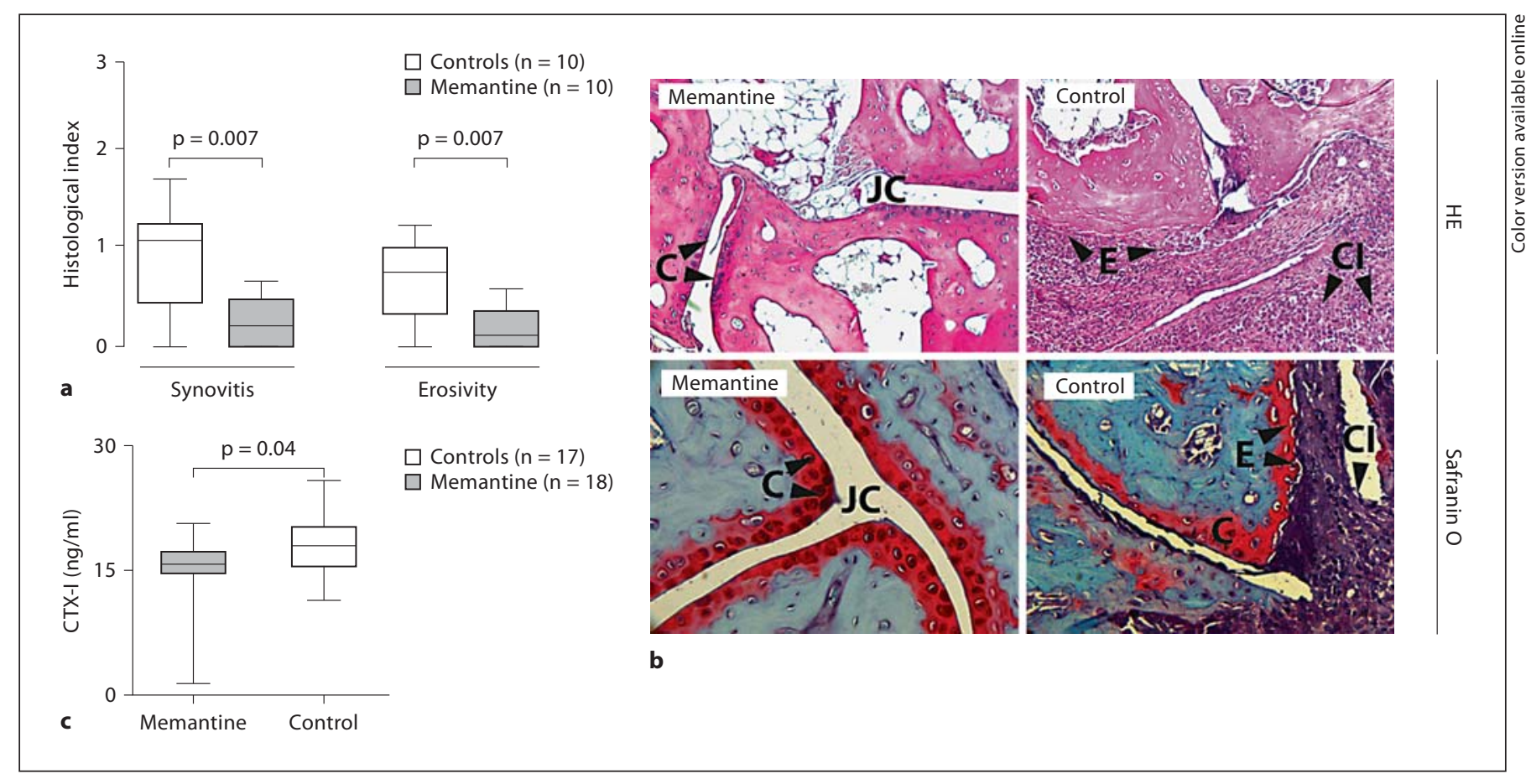

Fig. 2. Memantine diminishes synovitis and bone erosions in CIA. a Histological evaluation of paws at discontinuation of the experiment on day 36 showed significantly decreased severity of synovitis $(\mathrm{p}=0.007)$ and erosion $(\mathrm{p}=0.007)$ in memantine-treated mice $(\mathrm{n}=10)$ compared to PBS-treated controls $(\mathrm{n}=10)$. b Representative histological changes seen in the joints of memantine-treated mice and controls. Magnification $\times 50$. C $=$ Cartilage; $\mathrm{E}=$ erosion; $\mathrm{CI}=$ cellular infiltration; $\mathrm{JC}=$ joint cavity.

Table 1. Bone metabolism markers and cytokine IL-6

\begin{tabular}{lcccc}
\hline & $\begin{array}{l}\text { PBS-injected } \\
\text { controls }\end{array}$ & $\begin{array}{l}\text { Meman- } \\
\text { tine }\end{array}$ & KA & AIDA \\
\hline OPN, $\mu \mathrm{g} / \mathrm{ml}$ & $220 \pm 13$ & $177 \pm 10^{*}$ & $169 \pm 17$ & $182 \pm 18$ \\
OPG, $\mu \mathrm{g} / \mathrm{ml}$ & $6.5 \pm 0.8$ & $6.0 \pm 0.4$ & $6.0 \pm 0.6$ & $5.5 \pm 0.6$ \\
$\mathrm{RANKL}, \mathrm{ng} / \mathrm{ml}$ & $354 \pm 87$ & $385 \pm 59$ & $637 \pm 101$ & $275 \pm 82$ \\
$\mathrm{MMP}-3, \mathrm{ng} / \mathrm{ml}$ & $352 \pm 49$ & $343 \pm 79$ & - & - \\
$\mathrm{IL}-6, \mathrm{pg} / \mathrm{ml}$ & $82 \pm 19$ & $69 \pm 21$ & $85 \pm 20$ & - \\
\hline
\end{tabular}

The levels of the bone metabolism markers OPN, OPG, RANKL and MMP-3 were measured in sera from mice treated with memantine, KA and AIDA, and in PBS-injected controls.

Levels of OPG, RANKL and MMP-3 were similar in all groups, while the OPN levels were significantly decreased in the memantine-treated animals compared to controls ( $\left.{ }^{*} \mathrm{p}=0.046\right)$.

The inflammatory cytokine IL- 6 was surprisingly not significantly affected in the memantine-treated animals compared to controls.

All values are presented as mean \pm SEM. c Memantine-treated mice presented significantly lower serum levels of CTX-I, a marker of bone resorption, compared to PBStreated controls $(p=0.04)$. Values are presented as medians and IQR. Horizontal lines indicate the median, whiskers represent minimal and maximal values. Statistical evaluation was performed using the Mann-Whitney U test with Bonferroni correction.

\section{Memantine Activates B Cells and Increases Antigen Response}

Since anti-CII antibody production is essential in the development of CIA [30], the levels of anti-CII antibodies were measured at the end of the experiments with memantine and AIDA. Anti-CII antibody levels were significantly higher in the memantine-treated group than in vehicle-treated control animals $(\mathrm{p}=0.001$; fig. 3a). This difference was present in all three independent experiments (values were pooled and presented as a mean). For AIDA, no difference in antibodies was seen in comparison to control. Interestingly, no differences were found in the levels of antibodies against Fc-IgG (RF) or aCCP between the groups (fig. 3b). Since memantine treatment elicited a substantially different immunization response, the effects of memantine on B cells were evaluated. Spleen $B$ cells from mice treated with intraperitoneal injections with memantine or AIDA were analyzed. Although both antagonists caused enrichment of CD19+ B cells in the 
Fig. 3. Effect of memantine on B cell population and antibody production. The levels of antibodies against CII and CCP were measured at the end of the experiment using an ELISA. a Significantly higher levels of anti-CII antibodies were observed in the memantine-treated group $(\mathrm{n}=19)$ compared to the PBS-injected controls $(n=20)$. The levels of anti-CII antibodies were unaffected by AIDA treatment. $\mathbf{b}$ The levels of anti-CCP antibodies were similar in memantine-treated mice and PBS-injected controls. Mice were treated with memantine $(n=5)$ or AIDA $(n=5)$ for 7 days, after which the spleens were excised and subjected to flow cytometry. B cell populations were significantly enriched in the spleens of both memantine- and AIDA-treated mice $(\mathrm{p}=0.02$ and $\mathrm{p}=0.007$, respectively). d Mice treated with memantine, in contrast to AIDA-treated animals, showed an increase in CD25 expression on CD19+ B cells $(\mathrm{p}=0.006)$. Values are presented as medians and IQR. Horizontal lines indicate the median, whiskers represent minimal and maximal values. Statistical analyses for figure $\mathbf{a}$ and $\mathbf{b}$ were performed using Mann Whitney test, and for $\mathbf{c}$ and $\mathbf{d}$, they were performed using Students' $t$ test.

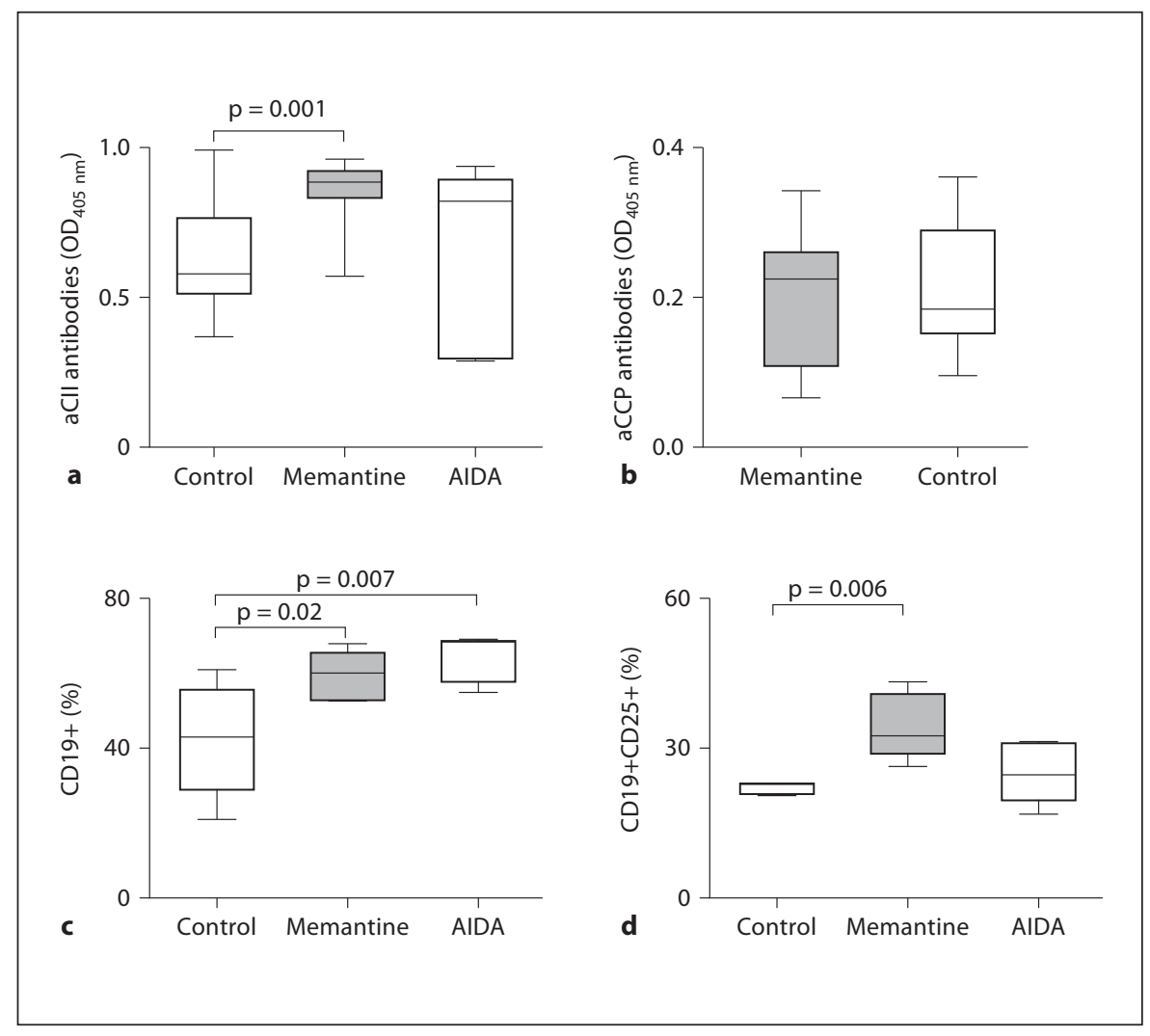

spleen (fig. 3c), this effect was more pronounced in the AIDA-treated mice in which the CD19+ B cell population comprised $68 \%$ of mononuclear cells. Additionally, memantine-treated mice exhibited increased CD25 levels on the surface of CD19+ cells ( $34 \pm 3.7)$ compared to controls (23 $\pm 0.7, \mathrm{p}=0.006)$ (fig. $3 \mathrm{~d}$ ); however, no significant increase was detected in mice treated with AIDA (27 \pm 3.4 ).

\section{Memantine Up-Regulated Expression of Foxp3 in \\ Spleen CD4+ T Cells}

CD4+ T cells were obtained from spleens of memantine- and AIDA-treated mice. Neither antagonist induced a significant enrichment in T cell numbers (not shown). Treatment with memantine resulted in increased expression of the transcription factor Foxp3 in CD4+ T cells, whereas no significant difference was detected following treatment with AIDA (fig. 4a). In memantine-treated mice, flow cytometry analysis of splenocytes showed a significant increase in the percentage of Foxp3+ cells as compared to the PBS-treated controls. With prolonged memantine treatment (12 days), the amount of Foxp3+ cells was 3 -fold higher than in controls $(p=0.006)$. Although not apparent after 7 days of treatment, a significant increase in the population of natural regulatory $\mathrm{T}$ cells, i.e. $\mathrm{CD} 4+\mathrm{CD} 25+$ Foxp3+ cells, was found after 12 days of memantine treatment (fig. $4 \mathrm{c} ; \mathrm{p}=0.003$ ). Interestingly, the $\mathrm{CD} 4+\mathrm{CD} 25+$ and CD4+CD25- populations of T cells remained unchanged during memantine treatment.

To confirm the regulatory function of the CD4+ $\mathrm{CD} 25+$ cells, the proliferation and cytokine profile of the CD4+CD25- cells was assessed in the presence of CD4+CD25+ cells obtained from memantine-treated mice $(n=6)$. The aCD3-induced proliferation of the CD $4+C D 25-$ effector $\mathrm{T}$ cells was decreased by $53 \%$ in the presence of $\mathrm{CD} 4+\mathrm{CD} 25+$ cells (4:1 ratio) as compared to CD4+CD25- cell cultures alone. In agreement with the proliferation results, we observed a significant decrease of IL-2, IL-4 and TNF- $\alpha$ levels in the supernatants of mixed $\mathrm{CD} 4+\mathrm{CD} 25+$ and $\mathrm{CD} 4+\mathrm{CD} 25$ - cultures as compared to the cultures containing CD4+CD25- cells alone (fig. 4d). Additionally, the supernatants of mixed CD4+CD25+ and CD4+CD25- cultures had significantly higher levels of IL-10 in the presence or absence of aCD3 as compared to CD4+CD25- cell cultures. The levels of IL-17 $\alpha$ and INF- $\gamma$ were not changed significantly (fig. $4 \mathrm{~d}$ ). 


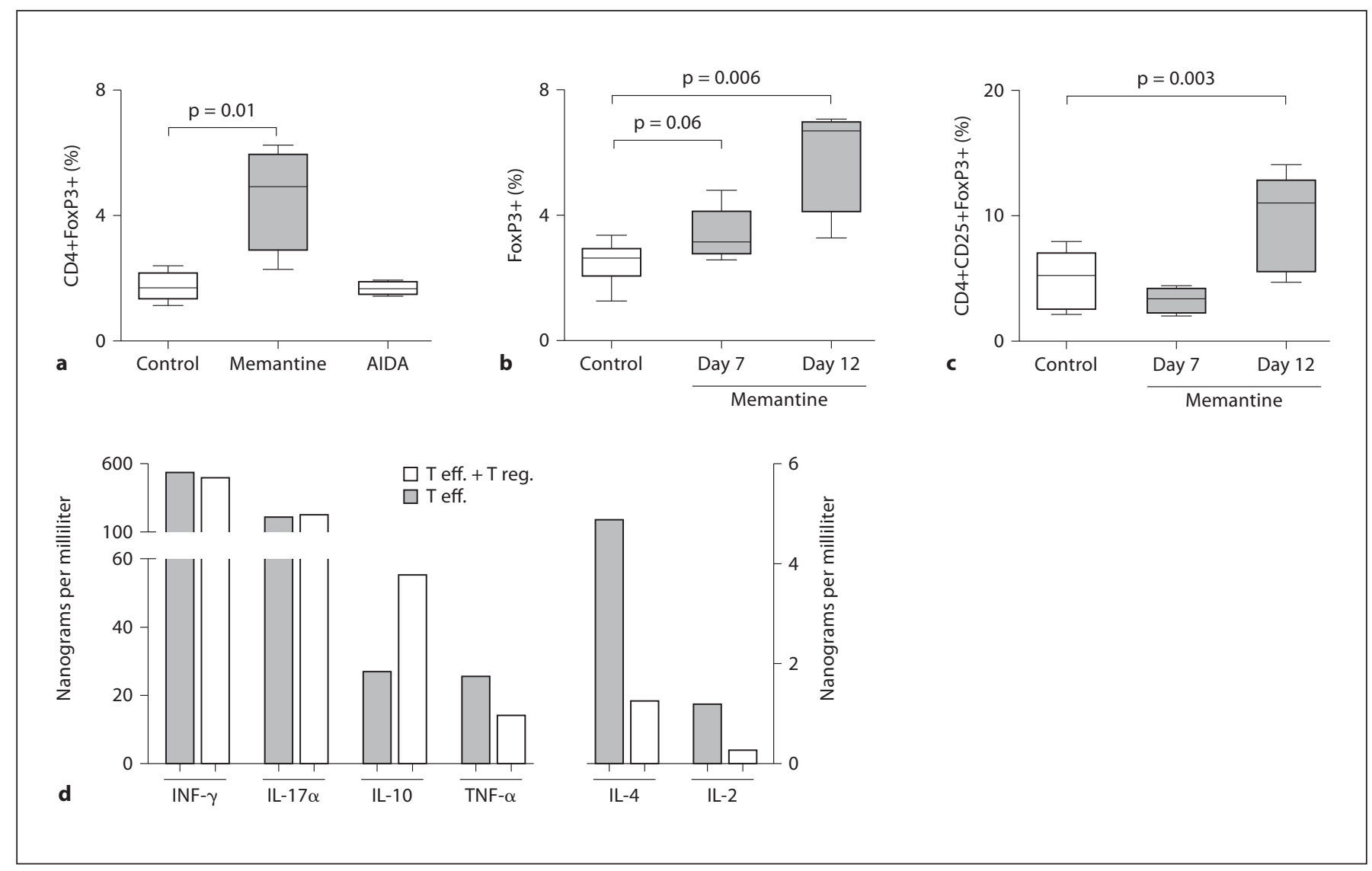

Fig. 4. Memantine induces the expression of Foxp3 transcription factor on CD4+ T cells. To assess the effect of memantine on the $\mathrm{T}$ cell populations, mice were treated with intraperitoneal injections with memantine $(\mathrm{n}=10)$ or AIDA $(\mathrm{n}=5)$, after which the spleens were excised and subjected to flow cytometry. Positive populations were set using FMO and an isotype control. a A significant increase in CD4+Foxp3+ expression in splenocytes was observed on day 12 of memantine treatment, as compared to PBSinjected controls $(\mathrm{p}=0.01)$. $\mathbf{b}$ Memantine showed a tendency to increase intracellular expression of Foxp3 in mononuclear cells after 7 days of treatment $(p=0.06)$, and the levels were increased further by day $12(\mathrm{p}=0.006)$. c Regulatory T cell populations were defined using a combination of CD4 and CD25. After 12 days of treatment, memantine increased the regulatory $\mathrm{T}$ cell population $(\mathrm{p}=0.003)$. Values are presented as medians and IQR. Horizontal lines indicate the median, whiskers represent minimal and maximal values. Statistical analyses were performed using Students' $t$ test. The supernatants of mixed CD4+CD25+ and CD4+CD25cultures (1:4) had higher levels of IL-10 in the presence of aCD3 as compared to CD4+CD25-cell cultures, while the levels of IL-2, IL- 4 and TNF- $\alpha$ were remarkably lower. Both IL-17 $\alpha$ and INF- $\gamma$ remained unchanged.

\section{Discussion}

This study shows that memantine-mediated blockade of the iGluR NMDA attenuates and delays the development of CIA in mice. It reduces leukocyte influx in the synovia and bone destruction, decreasing the number of erosions. In contrast, the mGluR antagonist AIDA and the excitatory amino acid receptor antagonist KA did not affect the development of CIA, which suggests that Glu facilitates arthritogenic processes via activation of NMDA receptors.

Our findings add new information to previous studies on NMDA receptor signalling performed in a variety of inflammatory models. In antigen-induced arthritis in rats, Boettger et al. [35] showed that intrathecal administration of the uncompetitive NMDA receptor channel blocker ketamine reduced pain and the severity of arthritis. This was characterized by reduced joint swelling and decreased infiltration of inflammatory cells into the joint cavity. Another uncompetitive NMDA receptor channel blocker, dizocilpine (MK-801), showed potent anti-inflammatory effects in a model of sepsis-associated lung 
injury in rats [36]. Administration of MK-801 reduced the cellular content in BAL fluid and decreased the levels of pro-inflammatory cytokines through a reduction in oxidative stress. Decrease in oxidative stress in a model of acute experimental colitis was achieved by treatment with KA [37]. Administration of competitive antagonists of the NMDA receptor was tested in arthritis models induced by injection of Freund's adjuvant [38] or carrageenan [39]. The derivates of the NMDA receptor antagonist phosphonovaleric acid 2-amino-5-phosphonopentanoic acid (AP5) and 2-amino-7-phosphonoheptanoic acid (AP7) provided intra-articularly reduced joint allodynia, swelling [38] and mechanical hypersensitivity [40]. In contrast, spinal administration of AP7 had no effect on carrageenan-induced arthritis [41].

Glu is thought to be an important messenger in bone cells, and mechanical forces applied to bones up-regulate Glu transporters [42]. NMDA agonists up-regulate RANKL-dependent osteoclastogenesis in vivo [43], and blockade of NMDA receptors reduces bone resorption [44]. In the mouse model of CIA used in this study, NMDA receptors were blocked by memantine treatment. This treatment significantly reduced bone resorption, as measured by CTX-I levels. It also reduced the frequency of histologically observed bone erosions. Memantine treatment did not significantly alter the levels of the osteocytokines RANKL or OPG, whereas it did decrease the levels of the osteoclast stimulator OPN. Interestingly, these effects can all be attributed to inhibition of the NMDA receptor since they were not observed in mice treated with AIDA or KA, which both are non-NMDA receptor antagonists. These findings are in agreement with previous observations showing that the NMDA receptor is a necessary modulator of bone formation as it is involved in osteoclast and osteoblast maturation $[42,45,46]$.

NMDA receptor subunits are found on resting rodent and human $\mathrm{T}$ lymphocytes. NMDA receptors are involved in modulating $\mathrm{T}$ cell functions including control of growth and adhesion to the extracellular matrix [47], as well as cytokine production $[26,48]$. In the present study, blockade of the NMDA receptor channel was associated with increased expression of Foxp3, a transcription factor characteristic of regulatory $\mathrm{T}$ cells. During memantine treatment, the initial up-regulation of Foxp3 expression was observed in CD4+ cells, followed by an increase in the $\mathrm{CD} 4+\mathrm{CD} 25+\mathrm{FoxP} 3+$ population. This observation suggests peripheral rather than thymic conversion of regulatory $\mathrm{T}$ cells. Importantly, the $\mathrm{CD} 4+\mathrm{CD} 25+\mathrm{Foxp} 3-$ cell population was the same in memantine-treated and control groups. $\mathrm{CD} 4+\mathrm{Foxp} 3+$ regu- latory $\mathrm{T}$ cells exert dominant control over the self-reactive $\mathrm{T}$ cell population, supporting the development of self-tolerance [49]. Importantly, intracellular up-regulation of Foxp3 is essential for the suppressive activity of $\mathrm{CD} 4+\mathrm{T}$ cells, and is directed predominantly towards self-reactive $\mathrm{T}$ cells rather than $\mathrm{T}$ cells recognizing exogenous antigens. The $\mathrm{CD} 4+\mathrm{CD} 25+$ cell population isolated from memantine-treated mice was comprised of $77.6 \%$ Foxp3+ cells. The results of the proliferation reaction proved the FoxP3+ population to be fully functional. It produced high levels of IL-10 and suppressed proliferation of CD4+CD25- cells.

It has been postulated that regulatory $\mathrm{T}$ cells may be formed either in the thymus or on the periphery via induction of FoxP3 expression in conventional CD4+ T cells $[50,51]$. IL- 2 and TGF- $\beta$ play central roles in triggering the expression of Foxp3 in CD4+ T cells. The differential intracellular signalling required for up-regulation of Foxp3 and commitment to a regulatory $\mathrm{T}$ cell lineage includes activation of NF- $\kappa \mathrm{B}$ and inhibition of Akt pathways. Similar shifts in intracellular signalling were described following stimulation of NMDA receptors [26]; however, the formation of regulatory $\mathrm{T}$ cells was not proved.

In this study, memantine treatment exerted a modulatory effect on B cells, leading to accumulation of CD19+ $B$ cells in the spleen and up-regulation of CD25 on the cell surface. Additionally, the levels of antigen-specific CII antibodies were higher in memantine-treated mice than in controls while the levels of antibodies against CCP remained similar. The production of antibodies against CII is thought to be important in CIA [52], and adoptive transfer of anti-CII antibodies results in inflammatory arthritis in non-immunized recipients [53]. Higher levels of CII antibodies may reflect activation of Ig-producing $\mathrm{B}$ cell clones, or may result from efficient antigen presentation involving activation of dendritic cells in addition to the $\mathrm{B}$ and $\mathrm{T}$ cells described above. A discrepancy between the production of antigen-specific antibodies and autoantibodies may be viewed as a relative suppression of self-reactive lymphocytes. These findings are in agreement with the observed upregulation of $\mathrm{CD} 4+\mathrm{CD} 25+\mathrm{Foxp} 3+$ regulatory $\mathrm{T}$ cells and CD19+CD25+ B cells. During the early phase of arthritis in mice, transfer of regulatory $\mathrm{T}$ cells decreases the severity and prevents progression of the disease, even though CII auto-antibody titers remain unaffected by the transfer of regulatory $\mathrm{T}$ cells [54]. The CD19+CD25+ B cell population is thought to perform immunoregulatory functions in humans and rodents [32], and these cells 
may have played a protective role in this study. In conclusion, memantine treatment alleviates arthritis via immunomodulatory effects that support the formation of regulatory $\mathrm{T}$ cells and diminishes bone resorption.

\section{Acknowledgments}

This work was funded by grants from the Medical Society of Göteborg, the Swedish Society of Medicine, Tore Nilsson Foundation, Swedish Association against Rheumatism, the King Gustaf V Foundation, the Swedish Medical Research Council, the Profes- sor Nanna Swartz Foundation, AME Wolff Foundation, Rune and Ulla Amlövs Trust, the Swedish Foundation for Strategic Research, the Pharmacist Hedberg Foundation, and the University of Göteborg, Family Thölen and Kristlers Foundation, Börje Dahlin's Foundation, Torsten Söderberg's Foundation, National Inflammation Network, Lundberg Foundation, the regional agreement on medical training and clinical research (ALF) between the Western Götaland county council and the University of Göteborg (LUA/ALF) and a grant from the European Commission (FP7HEALTH-F2-2010-261460).

We thank Mikael Brisslert for advice regarding evaluation of flow-cytometric analysis.

\section{References}

1 Andersson AK, Li C, Brennan FM: Recent developments in the immunobiology of rheumatoid arthritis. Arthritis Res Ther 2008;10:204.

-2 Beech JT, Andreakos E, Ciesielski CJ, Green P, Foxwell BM, Brennan FM: T-cell contactdependent regulation of $\mathrm{CC}$ and $\mathrm{CXC}$ chemokine production in monocytes through differential involvement of NF- $\mathrm{NB}$ : implications for rheumatoid arthritis. Arthritis Res Ther 2006;8:R168.

3 Tran CN, Lundy SK, White PT, Endres JL, Motyl CD, Gupta R, et al: Molecular interactions between T cells and fibroblast-like synoviocytes: role of membrane tumor necrosis factor- $\alpha$ on cytokine-activated T cells. Am J Pathol 2007;171:1588-1598.

$\checkmark 4$ Kotake S, Udagawa N, Hakoda M, Mogi M, Yano K, Tsuda E, et al: Activated human T cells directly induce osteoclastogenesis from human monocytes: possible role of T cells in bone destruction in rheumatoid arthritis patients. Arthritis Rheum 2001;44:1003-1012.

$\checkmark 5$ Fournier C: Where do T cells stand in rheumatoid arthritis? Joint Bone Spine 2005;72: 527-532.

66 Meldrum BS: Glutamate as a neurotransmitter in the brain: review of physiology and pathology. J Nutr 2000;130(suppl 4):1007S1015S.

7 McNearney T, Baethge BA, Cao S, Alam R, Lisse JR, Westlund KN: Excitatory amino acids, TNF- $\alpha$, and chemokine levels in synovial fluids of patients with active arthropathies. Clin Exp Immunol 2004;137:621-627.

$\checkmark 8$ McNearney T, Speegle D, Lawand N, Lisse J, Westlund KN: Excitatory amino acid profiles of synovial fluid from patients with arthritis. J Rheumatol 2000;27:739-745.

-9 Lawand NB, McNearney T, Westlund KN: Amino acid release into the knee joint: key role in nociception and inflammation. Pain 2000;86:69-74.
10 Hinoi E, Ohashi R, Miyata S, Kato Y, Iemata $\mathrm{M}$, Hojo $\mathrm{H}$, et al: Excitatory amino acid transporters expressed by synovial fibroblasts in rats with collagen-induced arthritis. Biochem Pharmacol 2005;70:17441755.

-11 Piepoli T, Mennuni L, Zerbi S, Lanza M, Rovati LC, Caselli G: Glutamate signaling in chondrocytes and the potential involvement of NMDA receptors in cell proliferation and inflammatory gene expression. Osteoarthritis Cartilage 2009; 17:1076-1083.

12 Flood S, Parri R, Williams A, Duance V, Mason D: Modulation of interleukin- 6 and matrix metalloproteinase 2 expression in human fibroblast-like synoviocytes by functional ionotropic glutamate receptors Arthritis Rheum 2007;56:2523-2534

-13 Boldyrev AA, Carpenter DO, Johnson P: Emerging evidence for a similar role of glutamate receptors in the nervous and immune systems. J Neurochem 2005;95:913-918.

14 Yanamala N, Tirupula KC, Klein-Seetharaman J: Preferential binding of allosteric modulators to active and inactive conformational states of metabotropic glutamate re ceptors. BMC Bioinformatics 2008;9(suppl 1):S16

15 Chen PE, Geballe MT, Stansfeld PJ, Johnston AR, Yuan H, Jacob AL, et al: Structural features of the glutamate binding site in recombinant NR1/NR2A N-methyl-D-aspartate receptors determined by site-directed mutagenesis and molecular modeling. Mol Pharmacol 2005;67:1470-1484.

16 Cull-Candy SG, Leszkiewicz DN: Role of distinct NMDA receptor subtypes at central synapses. Sci STKE 2004;2004:re16.

17 Huggins DJ, Grant GH: The function of the amino terminal domain in NMDA receptor modulation. J Mol Graph Model 2005;23: 381-388.

18 Berti M, Baciarello M, Troglio R, Fanelli G: Clinical uses of low-dose ketamine in patients undergoing surgery. Curr Drug Targets $2009 ; 10: 707-715$.
19 Leander JD, Lawson RR, Ornstein PL, Zimmerman DM: N-methyl-D-aspartic acid-induced lethality in mice: selective antagonism by phencyclidine-like drugs. Brain Res 1988; 448:115-120.

20 Kumari M, Ticku MK: Regulation of NMDA receptors by ethanol. Prog Drug Res 2000; 54:152-189.

21 Pin JP, Duvoisin R: The metabotropic glutamate receptors: structure and functions. Neuropharmacology 1995;34:1-26.

>22 Swanson CJ, Bures M, Johnson MP, Linden AM, Monn JA, Schoepp DD: Metabotropic glutamate receptors as novel targets for anxiety and stress disorders. Nat Rev Drug Discov 2005; 4:131-144.

23 Skeberdis VA, Lan J, Opitz T, Zheng X, Bennett MV, Zukin RS: mGluR1-mediated potentiation of NMDA receptors involves a rise in intracellular calcium and activation of protein kinase C. Neuropharmacology 2001; 40:856-865.

24 Levite M: Nervous immunity: neurotransmitters, extracellular $\mathrm{K}^{+}$and T-cell function. Trends Immunol 2001;22:2-5.

25 Gonoi T, Mizuno N, Inagaki N, Kuromi H, Seino Y, Miyazaki J, Seino S: Functional neuronal ionotropic glutamate receptors are expressed in the non-neuronal cell line MIN6. J Biol Chem 1994;269:16989-16992.

26 Kvaratskhelia E, Maisuradze E, Dabrundashvili NG, Natsvlishvili N, Zhuravliova E, Mikeladze DG: N-methyl-D-aspartate and sigma-ligands change the production of interleukins 8 and 10 in lymphocytes through modulation of the NMDA glutamate receptor. Neuroimmunomodulation 2009;16:201207.

27 Pacheco R, Ciruela F, Casado V, Mallol J, Gallart T, Lluis C, et al: Group I metabotropic glutamate receptors mediate a dual role of glutamate in $\mathrm{T}$ cell activation. J Biol Chem 2004;279:33352-33358.

28 Johnson JW, Kotermanski SE: Mechanism of action of memantine. Curr Opin Pharmacol 2006;6:61-67. 
-29 Toggas SM, Masliah E, Mucke L: Prevention of HIV-1 gp120-induced neuronal damage in the central nervous system of transgenic mice by the NMDA receptor antagonist memantine. Brain Res 1996;706:303-307.

-30 Verdrengh M, Jonsson IM, Holmdahl R, Tarkowski A: Genistein as an anti-inflammatory agent. Inflamm Res 2003;52:341-346.

>31 Chen W, Jin W, Hardegen N, Lei KJ, Li L, Marinos N, et al: Conversion of peripheral CD4+CD25- naive $\mathrm{T}$ cells to CD4+CD25+ regulatory $\mathrm{T}$ cells by TGF- $\beta$ induction of transcription factor Foxp3. J Exp Med 2003; 198:1875-1886.

>32 Amu S, Gjertsson I, Tarkowski A, Brisslert M: B-cell CD25 expression in murine primary and secondary lymphoid tissue. Scand J Immunol 2006;64:482-492.

-33 Lindblad SS, Mydel P, Jonsson IM, Senior RM, Tarkowski A, Bokarewa M: Smoking and nicotine exposure delay development of collagen-induced arthritis in mice. Arthritis Res Ther 2009;11:R88.

-34 Holmdahl R, Jansson L, Larsson A, Jonsson $\mathrm{R}$ : Arthritis in DBA/1 mice induced with passively transferred type II collagen immune serum. Immunohistopathology and serum levels of anti-type II collagen auto-antibodies. Scand J Immunol 1990;31:147-157.

-35 Boettger MK, Weber K, Gajda M, Bräuer R, Schaible HG: Spinally applied ketamine or morphine attenuate peripheral inflammation and hyperalgesia in acute and chronic phases of experimental arthritis. Brain Behav Immun 2010;24:474-485.

- 36 da Cunha AA, Pauli V, Saciura VC, Pires MG, Constantino LC, de Souza B, Petronilho F, Rodrigues de Oliveira J, Ritter C, Romão PR, Boeck CR, Roesler R, Quevedo J, DalPizzol F: N-methyl-D-aspartate glutamate receptor blockade attenuates lung injury associated with experimental sepsis. Chest 2010;137:297-302.
37 Varga G, Erces D, Fazekas B, Fülöp M, Kovács T, Kaszaki J, Fülöp F, Vécsei L, Boros M: N-Methyl-D-aspartate receptor antagonism decreases motility and inflammatory activation in the early phase of acute experimental colitis in the rat. Neurogastroenterol Motil 2010;22:217-225.

38 Lam FF, Ng ES: Substance P and glutamate receptor antagonists improve the anti-arthritic actions of dexamethasone in rats. Br J Pharmacol 2010;159:958-969.

39 Sluka KA, Jordan HH, Westlund KN: Reduction in joint swelling and hyperalgesia following post-treatment with a non-NMDA glutamate receptor antagonist. Pain 1994;59: 95-100.

40 Ivanusic JJ, Beaini D, Hatch RJ, Staikopoulos V, Sessle BJ, Jennings EA: Peripheral Nmethyl-D-aspartate receptors contribute to mechanical hypersensitivity in a rat model of inflammatory temporomandibular joint pain. Eur J Pain 2011;15:179-185.

41 Sluka KA, Westlund KN: Centrally administered non-NMDA but not NMDA receptor antagonists block peripheral knee joint inflammation. Pain 1993;55:217-225.

42 Mason DJ, Suva LJ, Genever PG, Patton AJ, Steuckle S, Hillam RA, et al: Mechanically regulated expression of a neural glutamate transporter in bone: a role for excitatory amino acids as osteotropic agents? Bone 1997;20:199-205.

43 Lin TH, Yang RS, Tang CH, Wu MY, Fu WM Regulation of the maturation of osteoblasts and osteoclastogenesis by glutamate. Eur J Pharmacol 2008;589:37-44.

44 Chenu C, Serre CM, Raynal C, Burt-Pichat B, Delmas PD: Glutamate receptors are expressed by bone cells and are involved in bone resorption. Bone 1998;22:295-299.

45 Patton AJ, Genever PG, Birch MA, Suva LJ, Skerry TM: Expression of an N-methyl-Daspartate-type receptor by human and rat osteoblasts and osteoclasts suggests a novel glutamate signaling pathway in bone. Bone 1998;22:645-649.
46 Laketic-Ljubojevic I, Suva LJ, Maathuis FJ, Sanders D, Skerry TM: Functional characterization of N-methyl-D-aspartic acid-gated channels in bone cells. Bone 1999;25:631637.

47 Miglio G, Dianzani C, Fallarini S, Fantozzi $\mathrm{R}$, Lombardi G: Stimulation of N-methyl-Daspartate receptors modulates Jurkat $\mathrm{T}$ cell growth and adhesion to fibronectin. Biochem Biophys Res Commun 2007;361:404409.

48 Mashkina AP, Tyulina OV, Solovyova TI, Kovalenko EI, Kanevski LM, Johnson P, et al: The excitotoxic effect of NMDA on human lymphocyte immune function. Neurochem Int 2007;51:356-360.

49 Fontenot JD, Rudensky AY: A well adapted regulatory contrivance: regulatory $\mathrm{T}$ cell development and the forkhead family transcription factor Foxp3. Nat Immunol 2005;6: 331-337.

-50 Feuerer M, Hill JA, Mathis D, Benoist C: Foxp3+ regulatory $\mathrm{T}$ cells: differentiation, specification, subphenotypes. Nat Immunol 2009; 10:689-695.

51 Wing K, Sakaguchi S: Regulatory T cells exert checks and balances on self tolerance and autoimmunity. Nat Immunol 2010;11:7-13.

52 Luross JA, Williams NA: The genetic and immunopathological processes underlying collagen-induced arthritis. Immunology 2001;103:407-416.

53 Watson WC, Brown PS, Pitcock JA, Townes AS: Passive transfer studies with type II collagen antibody in B10.D2/old and new line and $\mathrm{C} 57 \mathrm{Bl} / 6$ normal and beige (Chediak-Higashi) strains: evidence of important roles for C5 and multiple inflammatory cell types in the development of erosive arthritis. Arthritis Rheum 1987;30:460-465.

54 Morgan ME, Flierman R, van Duivenvoorde LM, Witteveen HJ, van Ewijk W, van Laar JM, et al: Effective treatment of collagen-induced arthritis by adoptive transfer of CD25+ regulatory T cells. Arthritis Rheum 2005;52:2212-2221. 